\title{
The apparent permeabilities of Caco-2 cells to marketed drugs: magnitude, and independence from both biophysical properties and endogenite similarities
}

Steve O'Hagan, Douglas B Kell

We bring together fifteen, nonredundant, tabulated collections (amounting to 696 separate measurements) of the apparent permeability $\left(\mathrm{P}_{\text {app }}\right)$ of Caco- 2 cells to marketed drugs. While in some cases there are some significant interlaboratory disparities, most are quite minor. Most drugs are not especially permeable through Caco-2 cells, with the median Papp value being some $16 \cdot 10^{-6} \mathrm{~cm}^{-1}$. This value is considerably lower than those (1310 and $230 \cdot 10^{-6} \mathrm{~cm} \cdot \mathrm{s}^{-1}$ ) recently used in some simulations that purported to show that Papp values were too great to be transporter-mediated only. While these values are outliers, all values, and especially the comparatively low values normally observed, are entirely consistent with transporter-only mediated uptake, with no need to invoke phospholipid bilayer diffusion. The apparent permeability of Caco-2 cells to marketed drugs is poorly correlated with either simple biophysical properties, the extent of molecular similarity to endogenous metabolites (endogenites), or any specific substructural properties. In particular, the octanol:water partition coefficient, $\log P$, shows negligible correlation with Caco-2 permeability. The data are best explained on the basis that most drugs enter (and exit) Caco-2 cells via a multiplicity of transporters of comparatively weak specificity. 
1 The apparent permeabilities of Caco- 2 cells to marketed drugs: 2 magnitude, and independence from both biophysical properties and 3 endogenite similarities

4

5

$6 \quad{ }^{1,2,3}$ Steve O'Hagan \& ${ }^{1,2,3,{ }^{*} \text { Douglas B. Kell }}$

$7{ }^{1}$ School of Chemistry, ${ }^{2}$ The Manchester Institute of Biotechnology, and ${ }^{3}$ Centre for Synthetic Biology of 8 Fine and Speciality Chemicals (SYNBIOCHEM), The University of Manchester, 131, Princess St, 9 Manchester M1 7DN, United Kingdom.

10 sohagan@manchester.ac.uk, dbk@manchester.ac.uk

11 *corresponding author: Tel 00441613064492 dbk@manchester.ac.uk http://dbkgroup.org @dbkell 
14 Abstract

15 We bring together fifteen, nonredundant, tabulated collections (amounting to 696 separate 16 measurements) of the apparent permeability $\left(\mathrm{P}_{\mathrm{app}}\right)$ of Caco-2 cells to marketed drugs. While in some 17 cases there are some significant interlaboratory disparities, most are quite minor. Most drugs are not 18 especially permeable through Caco-2 cells, with the median $P_{\text {app }}$ value being some $16.10^{-6} \mathrm{~cm} \cdot \mathrm{s}^{-1}$. This 19 value is considerably lower than those (1310 and $\left.230.10^{-6} \mathrm{~cm} \cdot \mathrm{s}^{-1}\right)$ recently used in some simulations that purported to show that $P_{\text {app }}$ values were too great to be transporter-mediated only. While these values are outliers, all values, and especially the comparatively low values normally observed, are entirely consistent with transporter-only mediated uptake, with no need to invoke phospholipid bilayer diffusion. The apparent permeability of Caco-2 cells to marketed drugs is poorly correlated with either simple biophysical properties, the extent of molecular similarity to endogenous metabolites (endogenites), or any specific substructural properties. In particular, the octanol:water partition coefficient, $\log \mathrm{P}$, shows negligible correlation with Caco-2 permeability. The data are best explained on the basis that most drugs enter (and exit) Caco-2 cells via a multiplicity of transporters of comparatively weak specificity.

\section{Keywords}

31 Caco-2 cells - Facilitated diffusion/transport - Mathematical models - Oral absorption - Permeability 32 Transcellular transport - Transporters 


\section{Introduction}

Most pharmaceutical drugs, and all oral ones, must necessarily cross at least one cell membrane to act. Understanding how this transport is effected remains a major challenge (Kell \& Oliver 2014). We have brought together considerable published evidence (e.g. (Dobson \& Kell 2008; Kell 2013; Kell 2015; Kell et al. 2013; Kell et al. 2011; Kell \& Oliver 2014)) that suggests that (in contrast to the general textbook belief, e.g. (Avdeef 2012; Cao et al. 2006; Krogsgaard-Larsen et al. 1996; van De Waterbeemd \& Testa 2009)) small molecule drugs 'hitchhike' on the many protein transporters (Kell 2013; Kell \& Goodacre 2014; Sahoo et al. 2014; Thiele et al. 2013) that are part of normal intermediary metabolism. These transporters may be identified via experiments where gene expression levels are manipulated systematically as independent variables (César-Razquin et al. 2015; Giacomini et al. 2010; Han et al. 2015; Kell \& Oliver 2014; Lanthaler et al. 2011; Winter et al. 2014). A number of recent books summarise the importance of protein transport to drug disposition (Bhardwaj et al. 2008; Ecker \& Chiba 2009; Fromm \& Kim 2011; Ishikawa et al. 2013; Sugiyama \& Steffansen 2013; You \& Morris 2014).

Caco-2 cells (e.g. (Artursson et al. 2001; Awortwe et al. 2014; Balimane \& Chong 2005; Fearn \& Hirst 2006; Feng et al. 2014; Hidalgo et al. 1989; Sarmento et al. 2012; Sun et al. 2008; van Breemen \& Li 2005; Volpe 2011)) are an epithelial cell line that has become a de facto standard in studies of pharmaceutical drug transport. They form a more or less (and otherwise) impermeable layer that is polarised, in the sense of having 'apical' and 'basolateral' faces in which transporters are differentially expressed. They express hundreds of transporters (Anderle et al. 2004; Hayeshi et al. 2008; Landowski et al. 2004; Pshezhetsky et al. 2007; Sun et al. 2002), and (although far from perfect (Hilgendorf et al. 2007)) they have significant predictive power as to the fraction of oral dose absorbed in humans (e.g. (Marino et al. 2005; Rubas et al. 1996)).

It is thus of general interest to understand the kinds of apparent permeability $\left(P_{\text {app }}\right)$ rates for different drug molecules that Caco-2 cells can sustain. Although there are undoubtedly larger databases in-house in commercial and other enterprises, we have sought to bring together what we can of published data to determine the kinds of permeability values that Caco-2 cells can sustain, and what might determine that. We recognise that many factors can affect a specific measurement, e.g. the seeding density, age of the cells, pH and so on. An interlaboratory comparison (Hayeshi et al. 2008) indicated that while on occasion measurements could vary by more than an order of magnitude, overall the groupings were normally reasonably tight (say within a factor of 2-5).

The question of $\mathrm{P}_{\mathrm{app}}$ values in Caco- 2 cells has been brought into sharper focus by a recent article (Matsson et al. 2015a; Matsson et al. 2015b) that claimed unusually high rates for verapamil and propranolol, based on measurements in a specific earlier article (Avdeef et al. 2005) in which stirring had been performed at a massive rate (and one not used in any equivalent transporter kinetics measurements). We indicated that these values were major outliers (by one or even two orders of magnitude) (Mendes et al. 2015), but did not pursue the question of what might be typical values of $P_{\text {app }}$ for other drugs. This is the focus of what we do here. 


\section{Methods}

Data were extracted manually from tables in the papers stated, and compiled as an Excel sheet. Typical biophysical descriptors were added using the RDKit module (Riniker \& Landrum 2013) of KNIME (Berthold et al. 2008; Mazanetz et al. 2012; Saubern et al. 2011) (www.knime.org/), essentially as described (O'Hagan \& Kell 2015a; O'Hagan \& Kell 2015b; O'Hagan et al. 2015). For one experiment we used the CDK-KNIME nodes (Beisken et al. 2013).

We have selected a set of 15 studies (indicated in the legend to Figure 1) for our analysis. Based on the list of FDA-approved drugs that we downloaded (as before (O'Hagan \& Kell 2015b; O'Hagan et al. 2015)) from DrugBank (http://drugbank.ca) (Law et al. 2014), we compiled from these a non-redundant set of measurements of the apparent permeability $\left(P_{a p p}\right.$, that are commonly given in units of $\left.\mathrm{cm} \cdot \mathrm{s}^{-1}\right)$. Although there are older papers, we have started with the compilation of Hou and colleagues (Hou et al. 2004). Our method for avoiding redundancy in later compilations was not to include a separate measurement if the numbers given were identical to those in Hou (Hou et al. 2004) (or any other later papers) to at least 1 decimal place. We ignore any efflux transporters, since the evidence (that we show later) is that their influence on these measurements is fairly small (Lin et al. 2011). We incorporated two values from the review of Marino and colleagues (Marino et al. 2005), one from lower throughput 24-well plates, one from a 96-well assay.

Where data were available for bidirectional assays, e.g. (Hayeshi et al. 2008; Skolnik et al. 2010) they are given just for the A $\rightarrow$ B direction. In the case of the interlaboratory comparison (Hayeshi et al. 2008), we used solely 'batch 1' data, while in the work of Lin et al. (Lin et al. 2011) efflux inhibitors were sometimes present, as noted below. The entire dataset is given as an Excel sheet as a Supplemental Table, and consists of 696 separate measurements. As indicated in Methods, we used KNIME to append some simple biophysical descriptors.

\section{Results}

Figure $1 \mathrm{~A}$ shows all of the data, with those studies finding rates above $100.10^{-6} \mathrm{~cm} \cdot \mathrm{s}^{-1}$ labelled with the study number. Of the 21 measurements that have this property, no fewer than 9 (labelled in red) are from a study (Avdeef et al. 2005) of Avdeef and colleagues. The largest values (Avdeef et al. 2005) were observed at very high values of stirring rates $(700 \mathrm{rpm})$, and these in particular contained a great many outliers. The implication is that these increases at exceptionally high stirring rates were due to unstirred layer effects, although it is hard to see their relevance to in vivo drug absorption where no such stirring is occurring. We also note (Dahlgren et al. 2015; Fagerholm \& Lennernäs 1995) that stirring has no effect on the transport of drugs through actual intestines. Mannitol is sometimes used as a membraneimpermeant control, taken to pass via a paracellular route. This said, mannitol controls did not always have the lowest values, and inulin (Marino et al. 2005) or EDTA (Lin et al. 2011) may be better. Although it was stated (Avdeef et al. 2005) that mannitol transport rates were 'normal', it is unclear why they do not change with stirring rates (or whether they do), so it is not entirely certain whether the epithelial layer remained intact, especially at some of the highest stirring rates employed. For these and other reasons, and especially given the strongly outlying nature of the measurements, we have decided for the rest of the analysis to exclude the data from (Avdeef et al. 2005), resulting in an overall dataset of 
112680 separate measurements as shown in Fig 1B. Although the $P_{\text {app }}$ values might vary somewhat with the 113 drug concentrations (e.g. (Engman et al. 2003)), we made no systematic attempt to take this into 114 account, since (i) often the drug concentration values appearing in the Tables from which we took the 115 data were not actually given, and (ii) this would not be expected to be by more than a factor 2, well 116 within the range of variation seen in individual measurements. A cumulative plot and smoothed 117 histogram of the data (Fig 1C) shows that the most abundant values for $\mathrm{P}_{\text {app }}$ are in the range 3 to $4.10^{-6}$ $118 \mathrm{~cm} \cdot \mathrm{s}^{-1}$, and with a median value of ca $16 \cdot 10^{-6} \mathrm{~cm} \cdot \mathrm{s}^{-1}$. Obviously these values are considerably lower than 119 those discussed in (Matsson et al. 2015a; Matsson et al. 2015b), and indicate (Mendes et al. 2015) that typical transporter kinetic parameters and expression levels are entirely adequate to account alone for cellular drug uptake, as proposed (Dobson et al. 2009a; Dobson \& Kell 2008; Kell 2013; Kell 2015; Kell \& Dobson 2009; Kell et al. 2013; Kell et al. 2011; Kell \& Goodacre 2014; Kell \& Oliver 2014; Kell et al. 2015).

The chief point of this high-level, overview paper is that the values of $P_{a p p}$ observed are typically rather low relative to those that can easily be explained of the basis of transporter-mediation only, without delving into minutiae. However, at the request of a reviewer we have added a Table (Table 1) that shows where available the concentrations of drug, insert type and stirring rates used in the relevant paper.

Figure 2 illustrates another feature of the data. Here we took the tabulated data of Lin, Skolnik and colleagues (Lin et al. 2011) that used a variety of efflux inhibitors. A comparison showed that no very substantial (order-of-magnitude) differences in uptake were observed (Fig 2), such that the typical 'low' values of $P_{a p p}$ cannot realistically be ascribed to a major role of efflux pumps.

Lack of relationship between Caco-2 permeability values and simple biophysical properties of drugs

134 If unstirred layer effects and pure diffusion (as opposed to transporter-based enzyme kinetics) were significant in Caco-2 permeability (notwithstanding the evidence that they are not (Fagerholm \& Lennernäs 1995)), one might suppose that permeability values should depend significantly upon the molecular mass of the drug involved. However, Fig $3 \mathrm{~A}$ shows that this is not the case, as the line of best fit has a slope of only $-0.04 \mathrm{X}$ and a value for $\mathrm{r}^{2}$ of just 0.069 . In a similar vein, despite a widespread view that transport rates should depend on log P, Fig 3B shows that even when the Caco-2 permeabilities are plotted in log space, the $r^{2}$ value for a plot against SlogP is only 0.011 . (For a plot in linear space the value drops to just $r^{2}=0.004$, data not shown.) There is a slightly clearer relationship between Caco-2 permeability and a drug's total polar surface area, but again the relationship is fairly weak $\left(r^{2}=0.334\right.$ when the ordinate is in log space, Fig $3 C$, but only $r^{2}=0.137$ when the ordinate is in linear space (plot not shown)). It is also of interest that there is no significant relationship between total Polar Surface Area and S logP (Fig 3D). In particular, as before, we (e.g. (Dobson \& Kell 2008; Kell \& Oliver 2014)) and terms of simple biophysical properties, and certainly not via logP. 
Lack of relationship between Caco-2 permeability and structural similarity to endogenous metabolites

Since the natural role of the transporters that drugs hitchhike on is to transport endogenous metaboliltes (Dobson \& Kell 2008; Kell 2013; Kell 2015; Kell et al. 2013; Kell \& Oliver 2014; Nigam 2015; Swainston et al. 2013), the 'principle of molecular similarity' (e.g. (Bender \& Glen 2004; Eckert \& Bajorath 2007; Gasteiger 2003; Maldonado et al. 2006)) suggests that drugs should bear structural similarities to endogenous metabolites, and this is found to be the case (Dobson et al. 2009b; O'Hagan \& Kell 2015b; O'Hagan et al. 2015). This led us to wonder whether any aspects of 'metabolite-likeness' might be related to Caco-2 permeability. However, we found no simple relationship of this type, whether (as illustrated) in terms of the closest Tanimoto similarity (Fig 4A) or (for the 61 molecules for which this was true) the count of endogenites exceeding a Tanimoto similarity of 0.65 (Fig 4B). (There was a very weak positive correlation, $r^{2}=0.156$, with the number of endogenites exceeding a Tanimoto similarity of 0.75 , for the 21 molecules that had at least one, data not shown.) One interpretation of this is that while in some cases a rather small number of transporters are typically involved in drug uptake (e.g. (Winter et al. 2014)), in many cases a considerably greater number contribute (e.g. (Kell et al. 2013; Lanthaler et al. 2011)). While well enough known in general (Mestres \& Gregori-Puigjané 2009), such 'promiscuity' has become much more manifest using modern chemical biology approaches to detect protein binding directly (e.g. (Li et al. 2010; Niphakis et al. 2015)).

Finally, we wondered whether a standard machine learning approach (a random forest learner (Breiman 2001; Fernández-Delgado et al. 2014; Knight et al. 2009; O'Hagan \& Kell 2015b)) might be able to predict Caco-2 permeabilities using a couple of fingerprint methods for encoding drug structures. Even this very powerful method had negligible predictive power as judged by its out-of-bag error (Fig 5). It must be concluded that the ability to pass through Caco-2 cells is a very heterogeneous property, that cannot be accounted for via simple biophysical properties (e.g. those contributing to log P), and is best explained by the intermediacy of a very heterogeneous set of transporters.

\section{Discussion and conclusions}

A recent publication (Matsson et al. 2015a; Matsson et al. 2015b), using exceptionally high values of $P_{\text {app }}$ for verapamil and propranolol, claimed that the apparent permeability values were such that they could not be supported by known (random) transporters at random expression level, $\mathrm{K}_{\mathrm{m}}$ and $\mathrm{k}_{\text {cat }}$ values. It was stated (Matsson et al. 2015a) that such rates "are possible in the absence of transmembrane diffusion, but only under very specific conditions that rarely or never occur for known human drug transporters". While we showed that this was simply not the case (quite the opposite) (Mendes et al. 2015), it prompted us to ask the question as to what typical rates of $\mathrm{P}_{\text {app }}$ might be for marketed drugs in Caco- 2 cells more generally. By bringing together tabulated data from 15 studies, we found that the commonest values are just ca $3-4 \cdot 10^{-6} \mathrm{~cm} \cdot \mathrm{s}^{-1}$, and that the median value is ca $16 \cdot 10^{-6} \mathrm{~cm} \cdot \mathrm{s}^{-1}$. Thus, transporters alone can easily account for these. There was no significant correlation of $P_{\text {app }}$ values with either the values of various biophysical descriptors or measures of endogenite-likeness, and even powerful machine learning methods could not predict the permeabilities from the drug structures. The most obvious reason for this is simply that there is no unitary explanation (such as simplistic phospholipid bilayer diffusion), as most drugs exploit multiple but often unknown transporters with overlapping 
188 specificities. Which they are and how much each contributes to a given Caco-2 permeability must be 189 determined by varying their activities as independent variables (Kell 2015; Kell \& Oliver 2014; Kell et al. 190 2015); César-Razquin et al. 2015), whether by using inhibitors (e.g. (Han et al. 2015; Ming et al. 2009)) or 191 genetically. This latter activity has been initiated in other cell lines (e.g. (Giacomini et al. 2010; Han et al. 192 2015; Lanthaler et al. 2011; Winter et al. 2014)). The availability of powerful mammalian genome editing 193 tools such as variants of the CRISPR/Cas9 system (e.g. (Kleinstiver et al. 2015; Maeder et al. 2013; Wang 194 et al. 2014; Zhou et al. 2014)) imply that we may soon expect to see this strategy applied with great 195 effect to the Caco-2 system.

196

197

198 
199 Figures and legends to figures

200

201

A

202

$10^{5} \cdot$ Caco- $2 \mathrm{P}_{\mathrm{spp}} / \mathrm{cm} \cdot \mathrm{s}^{-1}$

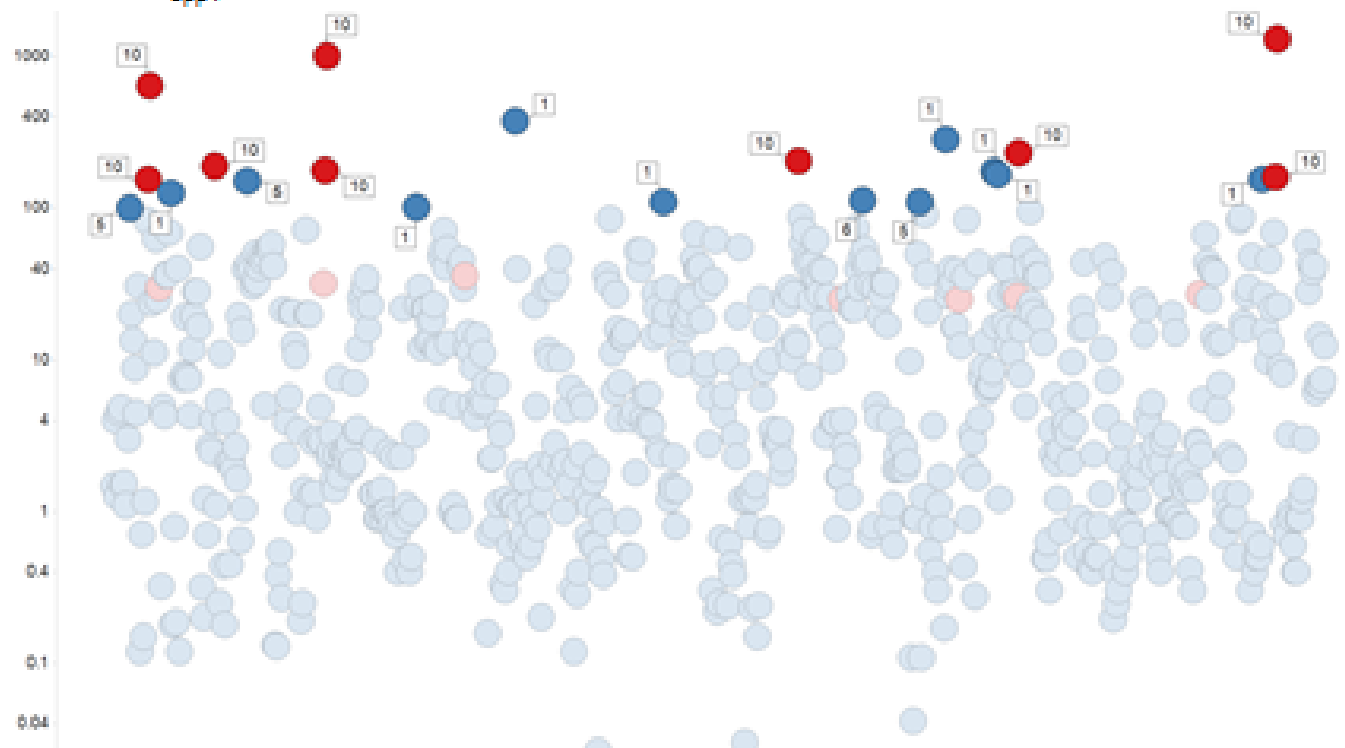

Various marketed drugs

B

\section{Reduced dataset used in study}

$10^{5} \cdot$ Caco- $2 \mathrm{P}_{\mathrm{spp}} / \mathrm{cm} \cdot \mathrm{s}^{-1}$

450

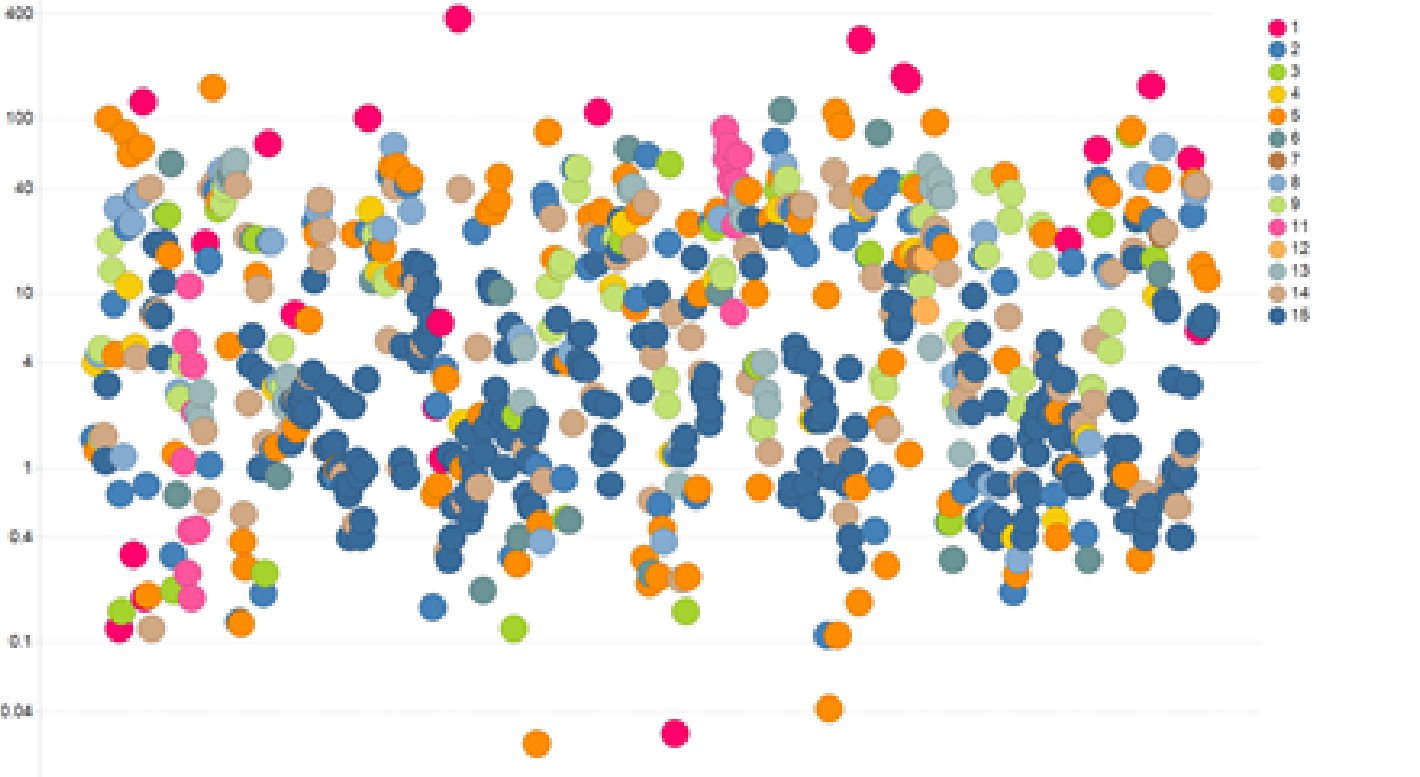

Various marketed drugs 
C

217 Figure 1. A compilation of 15 review articles on Caco-2 permeability measurements. A. Full dataset, 218 including outliers. B. Reduced dataset after removal of the data from (Avdeef et al. 2005). C. Cumulative 219 plot and smoothed histogram of the Caco-2 permeabilities in the reduced dataset. In Figure $1 \mathrm{C}$ data for identical drugs were averaged. Data were extracted from the following papers. 1 (Bergström et al. 2003); 2 (Hou et al. 2004); 3 (Corti et al. 2006); 4 (Balimane et al. 2006); 5 (Gozalbes et al. 2011); 6 (Peng et al. 2014); 7 (Press 2011); 8 (Usansky \& Sinko 2005); 9 (Marino et al. 2005); 10 (Avdeef et al. 2005); 11 (Hayeshi et al. 2008); 12 (Wang et al. 2010); 13 (Uchida et al. 2009); 14 (Skolnik et al. 2010); 15 (Lin et al. 2011) 


\section{Effects of efflux inhibitors on Caco-2 permeability}

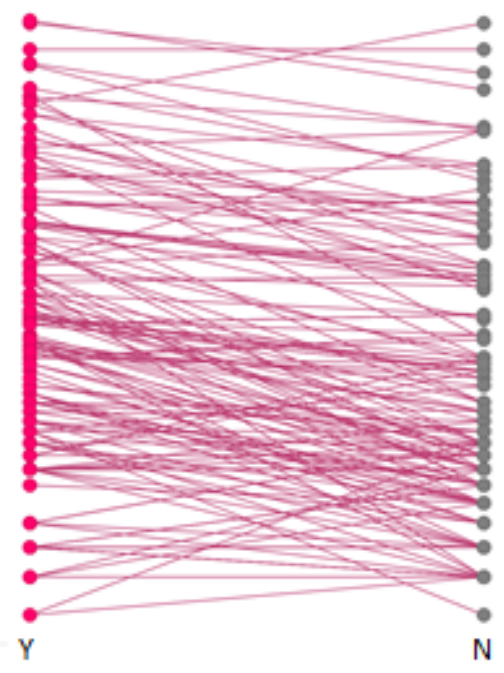

Efflux inhibitor
Efflux inhibitor

$\mathrm{Y}$

239

240

241

Figure 2. Relative lack of effect of efflux inhibitors on Caco-2 permeabilities of marketed drugs. Data are 242 taken from (Lin et al. 2011) and shown as paired values.

243 


\section{A Lack of relationship between Caco-2 permeability and MW} $10^{5}$. Caco- $2 \mathrm{P}_{\mathrm{spp}} / \mathrm{cm} \cdot \mathrm{s}^{-1}$

250

251

252

253

254

255

256

257

\section{B}

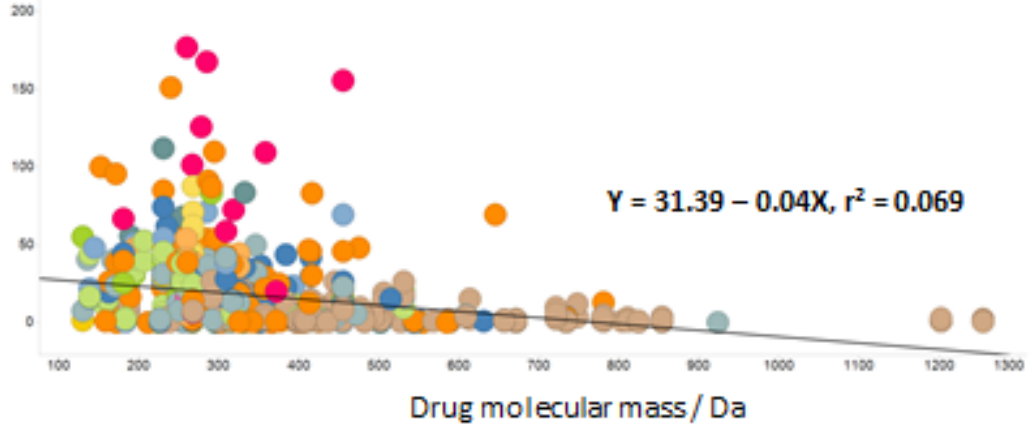

Reference

350

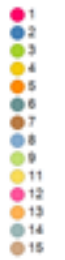

$$
\infty
$$

250

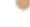


C

\section{Lack of relationship between Caco-2 permeability and TPSA}

273

274

275

276

277

278

279 $10^{6}$. Caco-2 $\mathrm{P}_{\text {app }} / \mathrm{cm} \cdot \mathrm{s}^{-1}$

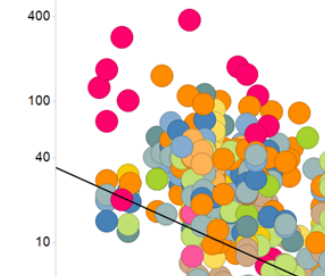
$\mathrm{Y}=1.42+0.01 \mathrm{X}, \mathrm{r}^{2}=0.334$
(on linear ordinate $r^{2}=0.137$ )

Reference

74

\section{5}

78

280

281

282

283

284

285

286

287

288

289

290

291

292

D

\section{Lack of relationship between Caco-2 TPSA and SlogP}

Total Polar Surface Area / $\AA^{2}$

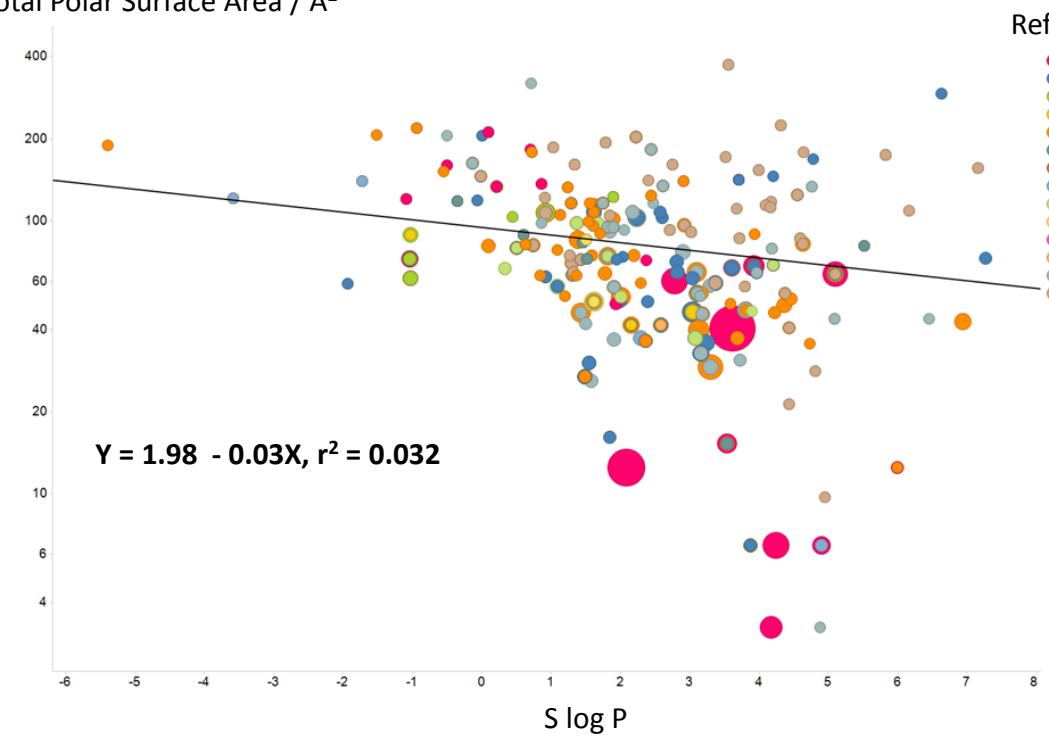

293 Figure 3. Lack of relationship between Caco-2 cells and simple biophysical parameters. A. Caco-2 294 permeability as a function of MW. B. Caco-2 permeability as a function of SlogP. C. Caco-2 permeability 
295

296

as a function of Total Polar Surface Area. $\log P$.

297

298

299

300

301

302

303

304

305

306

307

308

309

310

\section{A Lack of relationship between $P_{\text {app }}$ and Max TS}

$10^{5}$. Caco- $2 \mathrm{P}_{\mathrm{spp}} / \mathrm{cm} \cdot \mathrm{s}^{-1}$

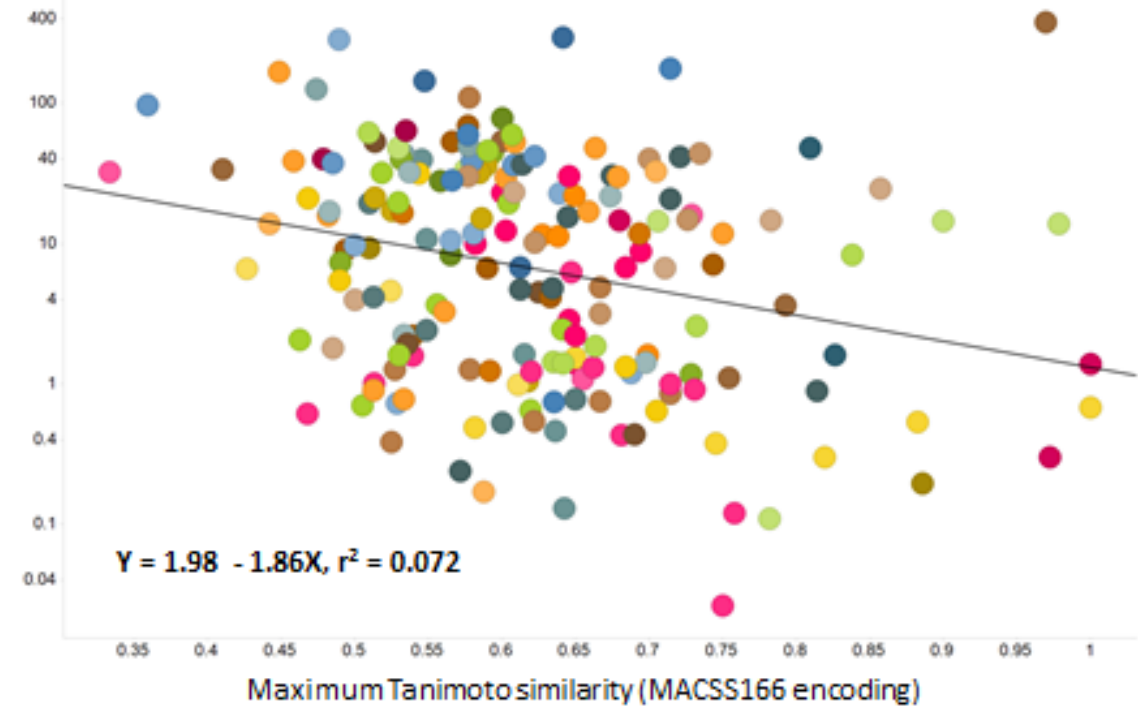

311

312

B Lack of relationship between $P_{\text {app }}$ and number of endogenites with a TS > 0.65

313 $10^{5}$. Caco- $2 \mathrm{P}_{\mathrm{spp}} / \mathrm{cm} \cdot \mathrm{s}^{-1}$

314

315

316

317

318

$\infty 0$

$\infty$

*

$\infty$

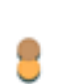

$\bullet$

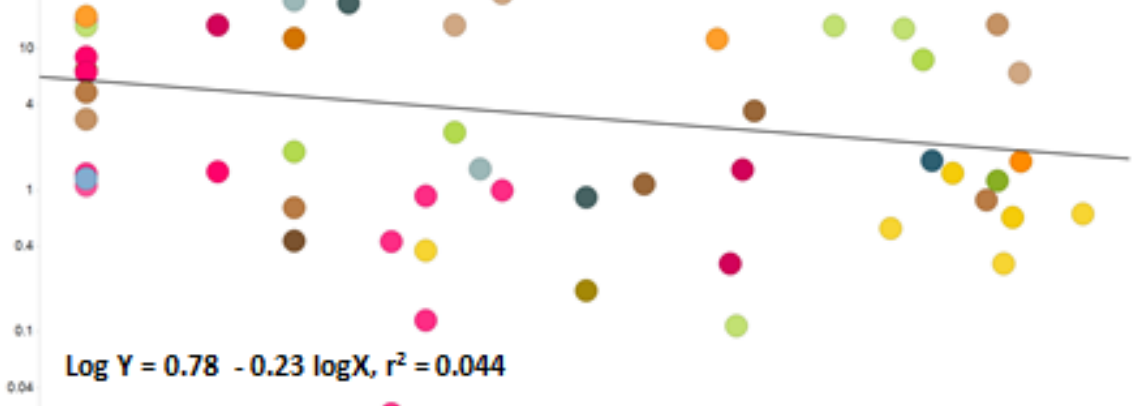

bot

Number of endogenites with Tanimoto similarity $>0.65$ (DESencoding) 
322 Figure 4. Lack of relationship between Caco-2 cell permeability and measures of endogenite-likeness. A. Lack of relationship between the $\mathrm{P}_{\text {app }}$ of a drug in Caco-2 cells and its greatest Tanimoto similarity to any endogenite molecule in Recon2. B. Lack of relationship between the $P_{\text {app }}$ of a drug and the number of endogenous metabolites (endogenites) in Recon2 possessing a Tanimoto similarity greater than 0.65. 187 different drugs were assessed in each case.

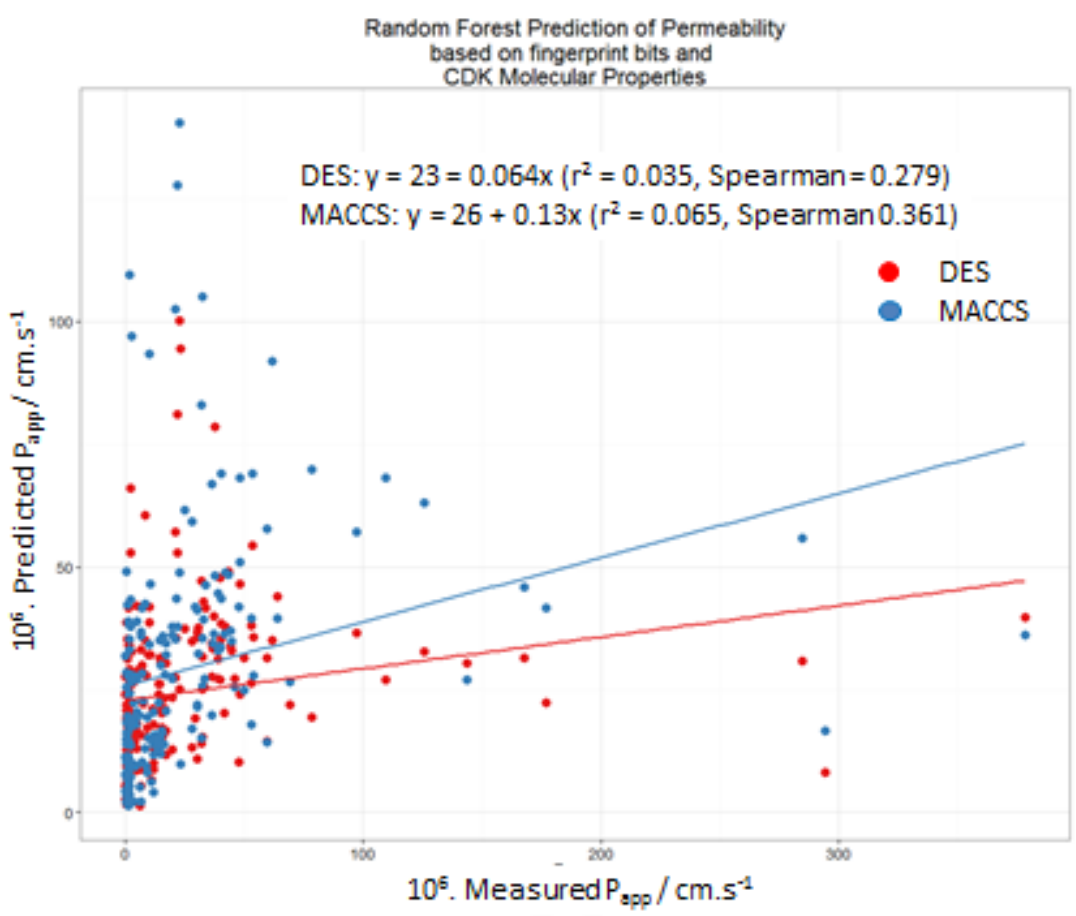

Figure 5. Lack of relationship between experimental Caco-2 permeabilities and those predicted (via outof-bag estimation) from a random forest learner. Drug properties were encoded using either the MACCS166 encoding (O'Hagan et al. 2015) or the full DES encoding (O'Hagan \& Kell 2015b), each together with the molecular properties encoded in the CDK KNIME node (Beisken et al. 2013).

Table 1. Further details of the 15 transporter studies reviewed.

\begin{tabular}{|l|l|l|l|}
\hline Drug concentration(s) & Insert type & $\begin{array}{l}\text { Shaking or stirring } \\
\text { speeds given }\end{array}$ & Reference \\
\hline $0.02-6 \mathrm{mM}$ & $\begin{array}{l}\text { Polycarbonate filter } \\
\text { inserts, } 12 \mathrm{~mm}\end{array}$ & Mainly $500 \mathrm{rpm}$ & Bergström et al. 2003 \\
\hline
\end{tabular}




\begin{tabular}{|c|c|c|c|}
\hline & $\begin{array}{l}\text { diameter; pore size } 0.4 \\
\mu \mathrm{m} \text {; Costar }\end{array}$ & & \\
\hline 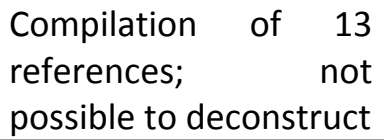 & & & Hou et al. 2004 \\
\hline Not actually stated & $\begin{array}{l}\text { Polycarbonate filters } \\
\left.\text { (area } 1.13 \mathrm{~cm}^{2}\right) \text { in } \\
\text { Costar Snapwell six- } \\
\text { well plates }\end{array}$ & Not stated & Corti et al. 2006 \\
\hline $100-200 \mu \mathrm{M}$ & $\begin{array}{lr}\begin{array}{l}\text { Corning } \\
\text { polycarbonate }\end{array} & \text { filter } \\
\text { membrane } & \text { (HTS- } \\
\text { Transwell inserts, } \\
\text { surface area: } 0.33 \mathrm{~cm}^{2}\end{array}$ & Not stated & Balimane et al. 2006 \\
\hline $10 \mu \mathrm{M}$ & $\begin{array}{l}\text { Fibrillar collagen } \\
\text { coated PET membrane } \\
\text { inserts in 24-well } \\
\text { plates (BD Biosciences) }\end{array}$ & Not stated & Gozalbes et al. 2011 \\
\hline $10 \mu \mathrm{M}$ & $\begin{array}{l}\text { Collagen-coated } \\
\text { transwell plates }\end{array}$ & $100 \mathrm{rpm}$ & Peng et al. 2014 \\
\hline $1-10 \mu \mathrm{M}$ & $\begin{array}{l}\text { (24-well systems from } \\
\text { BD BioSciences (PET } \\
\text { membrane, } 1.0 \mathrm{~mm} \text {, } \\
\text { cat. \#351181) or } \\
\text { Costar (polycarbonate } \\
\text { membrane, } 0.4 \mathrm{~mm} \text {, } \\
\text { cat. \#3396). }\end{array}$ & $30 \mathrm{rpm}$ & Press 2011 \\
\hline $\begin{array}{l}\text { Compilation; not } \\
\text { possible to deconstruct }\end{array}$ & & & Usansky \& Sinko 2005 \\
\hline $5 \mu \mathrm{M}$ & 'filter membranes' & Not stated & Marino et al. 2005 \\
\hline $50 \mathrm{nM}-100 \mu \mathrm{M}$ & $\begin{array}{l}\text { Polycarbonate filter } \\
\text { inserts (Transwell }{ }^{\circledR} \\
\text { Costar; mean pore size } \\
0.45 \mu \mathrm{m} \text {; diameters } 12 \\
\mathrm{~mm} \text { ) }\end{array}$ & $25-7000 \mathrm{rpm}$ & Avdeef et al. 2005 \\
\hline $\begin{array}{l}\text { Mostly } 30 \mu \mathrm{M} \\
\text { occasionally } 100 \mu \mathrm{M}\end{array}$ & $\begin{array}{l}\text { Polycarbonate, } 0.4-3 \\
\mu \mathrm{m}, 6 \mathrm{~mm} \text { or } 12 \mathrm{~mm}\end{array}$ & Not stated & Hayeshi et al. 2008 \\
\hline $10-500 \mu \mathrm{M}$ & $\begin{array}{l}\text { 12-well Transwell } \\
\text { plate with clear } \\
\text { polyester membrane } \\
\text { insert }(0.4 \mu \mathrm{m} \text { pore } \\
\text { diameter, } 12 \mathrm{~mm} \\
\text { diameter), Corning } \\
\text { Costar }\end{array}$ & $50 \mathrm{rpm}$ & Wang et al. 2010 \\
\hline $20 \mu \mathrm{M}$ & $\begin{array}{l}\text { 'Collagen-coated } \\
\text { inserts' }\end{array}$ & Not stated & Uchida et al. 2009 \\
\hline $10 \mu \mathrm{M}$ & “96-Multiwell & Yes, but rate not & Skolnik et al. 2010 \\
\hline
\end{tabular}




\begin{tabular}{|l|l|l|l|}
\hline & $\begin{array}{l}\text { System from BD } \\
\text { Biosciences" }\end{array}$ & stated & \\
\hline $10 \mu \mathrm{M}$ & $\begin{array}{l}\text { Six-well Transwell } \\
\text { polycarbonate } \\
\text { membrane inserts, } \\
\text { Corning Life Science }\end{array}$ & Not stated & Lin et al. 2011 \\
\hline
\end{tabular}

348

349

350

351

352

353

354

355

356

357

358

359

360

361

362

363

364

365

366

367

368

369

370

371

372

373

374

375

376

377

378

379

380

381

382

\section{Supplemental Table}

Set of Caco-2 permeabilities and RDKit descriptors used herein. Excel file.

Drugs_Caco2_compilation_with_descriptors_2.xls

Anderle P, Huang Y, and Sadée W. 2004. Intestinal membrane transport of drugs and nutrients: genomics of membrane transporters using expression microarrays. Eur J Pharm Sci 21:17-24.

Artursson P, Palm K, and Luthman K. 2001. Caco-2 monolayers in experimental and theoretical predictions of drug transport. Adv Drug Deliv Rev 46:27-43.

Avdeef A. 2012. Absorption and drug development: solubility, permeability and charge state. New York: Wiley.

Avdeef A, Artursson P, Neuhoff S, Lazorova L, Gråsjö J, and Tavelin S. 2005. Caco-2 permeability of weakly basic drugs predicted with the double-sink PAMPA pKa(flux) method. Eur J Pharm Sci 24:333-349.

Awortwe C, Fasinu PS, and Rosenkranz B. 2014. Application of Caco-2 cell line in herb-drug interaction studies: current approaches and challenges. J Pharm Pharm Sci 17:1-19.

Balimane PV, and Chong S. 2005. Cell culture-based models for intestinal permeability: a critique. Drug Discov Today 10:335-343.

Balimane PV, Han YH, and Chong SH. 2006. Current industrial practices of assessing permeability and Pglycoprotein interaction. Aaps J 8:E1-E13.

Beisken S, Meinl T, Wiswedel B, de Figueiredo LF, Berthold M, and Steinbeck C. 2013. KNIME-CDK: Workflow-driven cheminformatics. BMC Bioinformatics 14:257.

Bender A, and Glen RC. 2004. Molecular similarity: a key technique in molecular informatics. Org Biomol Chem 2:3204-3218.

Bergström CAS, Strafford M, Lazorova L, Avdeef A, Luthman K, and Artursson P. 2003. Absorption classification of oral drugs based on molecular surface properties. J Med Chem 46:558-570.

Berthold MR, Cebron N, Dill F, Gabriel TR, Kötter T, Meinl T, Ohl P, Sieb C, Thiel K, and Wiswedel B. 2008. KNIME: the Konstanz Information Miner. In: Preisach C, Burkhardt H, Schmidt-Thieme L, and Decker R, eds. Data Analysis, Machine Learning and Applications. Berlin: Springer, 319-326.

Bhardwaj RK, Herrera-Ruiz DR, Xu Y, Carl SM, Cook TJ, Vorsa N, and Knipp GT. 2008. Intestinal transporters in drug absorption. In: Krishna R, and Yu L, eds. Biopharmaceutics Applications in Drug Development. Berlin: Springer, 175-261.

Breiman L. 2001. Random forests. Machine Learning 45:5-32.

Cao X, Yu LX, and Sun D. 2006. Drug Absorption Principles. In: Krishna R, and Yu L, eds. Biopharmaceutics Applications in Drug Development. New York: Springer, 75-100. 
César-Razquin A, Snijder B, Frappier-Brinton T, Isserlin R, Gyimesi G, Bai X, Reithmeier RA, Hepworth D, Hediger MA, Edwards AM, and Superti-Furga G. 2015. A call for systematic research on solute carriers. Cell 162:478-487.

Corti G, Maestrelli F, Cirri M, Zerrouk N, and Mura P. 2006. Development and evaluation of an in vitro method for prediction of human drug absorption - II. Demonstration of the method suitability. Eur J Pharm Sci 27:354-362.

Dahlgren D, Roos C, Sjögren E, and Lennernäs H. 2015. Direct In Vivo Human Intestinal Permeability ( $P_{\text {eff }}$ ) Determined with Different Clinical Perfusion and Intubation Methods. J Pharm Sci 104:27022726.

Dobson P, Lanthaler K, Oliver SG, and Kell DB. 2009a. Implications of the dominant role of cellular transporters in drug uptake. Curr Top Med Chem 9:163-184.

Dobson PD, and Kell DB. 2008. Carrier-mediated cellular uptake of pharmaceutical drugs: an exception or the rule? Nat Rev Drug Disc 7:205-220.

Dobson PD, Patel Y, and Kell DB. 2009b. "Metabolite-likeness" as a criterion in the design and selection of pharmaceutical drug libraries. Drug Disc Today 14:31-40.

Ecker G, and Chiba P. 2009. Transporters as drug carriers: structure, function, substrates. Weinheim: Wiley/VCH.

Eckert $\mathrm{H}$, and Bajorath J. 2007. Molecular similarity analysis in virtual screening: foundations, limitations and novel approaches. Drug Discov Today 12:225-233.

Engman H, Tannergren C, Artursson P, and Lennernäs H. 2003. Enantioselective transport and CYP3A4mediated metabolism of R/S-verapamil in Caco-2 cell monolayers. Eur J Pharm Sci 19:57-65.

Fagerholm U, and Lennernäs H. 1995. Experimental Estimation of the Effective Unstirred Water Layer Thickness in the Human Jejunum, and Its Importance in Oral Drug Absorption. Eur J Pharm Sci 3:247-253.

Fearn RA, and Hirst BH. 2006. Predicting oral drug absorption and hepatobiliary clearance: Human intestinal and hepatic in vitro cell models. Env Toxicol Pharmacol 21:168-178.

Feng B, Varma MV, Costales C, Zhang H, and Tremaine L. 2014. In vitro and in vivo approaches to characterize transporter-mediated disposition in drug discovery. Expert Opin Drug Discov 9:873890.

Fernández-Delgado M, Cernadas E, Barro S, and Amorim D. 2014. Do we Need Hundreds of Classifiers to Solve Real World Classification Problems? J Machine Learning Res 15:3133-3181.

Fromm MF, and Kim RB. 2011. Drug Transporters. Handbook of Experimental Pharmacology Berlin: Springer.

Gasteiger J. 2003. Handbook of Chemoinformatics: From Data to Knowledge. Weinheim: Wiley/VCH.

Giacomini KM, Huang SM, Tweedie DJ, Benet LZ, Brouwer KL, Chu X, Dahlin A, Evers R, Fischer V, Hillgren KM, Hoffmaster KA, Ishikawa T, Keppler D, Kim RB, Lee CA, Niemi M, Polli JW, Sugiyama Y, Swaan PW, Ware JA, Wright SH, Wah Yee S, Zamek-Gliszczynski MJ, and Zhang L. 2010. Membrane transporters in drug development. Nat Rev Drug Discov 9:215-236.

Gozalbes R, Jacewicz M, Annand R, Tsaioun K, and Pineda-Lucena A. 2011. QSAR-based permeability model for drug-like compounds. Bioorg Med Chem 19:2615-2624.

Han TK, Proctor WR, Costales CL, Cai H, Everett RS, and Thakker DR. 2015. Four cation-selective transporters contribute to apical uptake and accumulation of metformin in Caco-2 cell monolayers. J Pharmacol Exp Ther 352:519-528.

Hayeshi R, Hilgendorf C, Artursson P, Augustijns P, Brodin B, Dehertogh P, Fisher K, Fossati L, Hovenkamp E, Korjamo T, Masungi C, Maubon N, Mols R, Müllertz A, Mönkkönen J, O'Driscoll C, Oppers-Tiemissen HM, Ragnarsson EG, Rooseboom M, and Ungell AL. 2008. Comparison of drug transporter gene expression and functionality in Caco-2 cells from 10 different laboratories. Eur J Pharm Sci 35:383-396. 
431

432

433

434

435

436

437

438

439

440

441

442

443

444

445

446

447

448

449

450

451

452

453

454

455

456

457

458

459

460

461

462

463

464

465

466

467

468

469

470

471

472

473

474

475

476

477

478

Hidalgo IJ, Raub TJ, and Borchardt RT. 1989. Characterization of the human colon carcinoma cell line (Caco-2) as a model system for intestinal epithelial permeability. Gastroenterology 96:736-749.

Hilgendorf C, Ahlin G, Seithel A, Artursson P, Ungell AL, and Karlsson J. 2007. Expression of thirty-six drug transporter genes in human intestine, liver, kidney, and organotypic cell lines. Drug Metab Dispos 35:1333-1340.

Hou TJ, Zhang W, Xia K, Qiao XB, and Xu XJ. 2004. ADME evaluation in drug discovery. 5. Correlation of Caco-2 permeation with simple molecular properties. J Chem Inf Comput Sci 44:1585-1600.

Ishikawa T, Kim RB, and König J. 2013. Pharmacogenomics of Human Drug Transporters: Clinical Impacts New York: Wiley.

Kell DB. 2013. Finding novel pharmaceuticals in the systems biology era using multiple effective drug targets, phenotypic screening, and knowledge of transporters: where drug discovery went wrong and how to fix it. Febs J 280:5957-5980.

Kell DB. 2015. What would be the observable consequences if phospholipid bilayer diffusion of drugs into cells is negligible? Trends Pharmacol Sci 36:15-21.

Kell DB, and Dobson PD. 2009. The cellular uptake of pharmaceutical drugs is mainly carrier-mediated and is thus an issue not so much of biophysics but of systems biology. In: Hicks MG, and Kettner C, eds. Proc Int Beilstein Symposium on Systems Chemistry. Berlin: Logos Verlag, 149-168 http://www.beilstein-institut.de/Bozen2008/Proceedings/Kell/Kell.pdf.

Kell DB, Dobson PD, Bilsland E, and Oliver SG. 2013. The promiscuous binding of pharmaceutical drugs and their transporter-mediated uptake into cells: what we (need to) know and how we can do so. Drug Disc Today 18:218-239.

Kell DB, Dobson PD, and Oliver SG. 2011. Pharmaceutical drug transport: the issues and the implications that it is essentially carrier-mediated only. Drug Disc Today 16:704-714.

Kell DB, and Goodacre R. 2014. Metabolomics and systems pharmacology: why and how to model the human metabolic network for drug discovery. Drug Disc Today 19:171-182.

Kell DB, and Oliver SG. 2014. How drugs get into cells: tested and testable predictions to help discriminate between transporter-mediated uptake and lipoidal bilayer diffusion. Front Pharmacol 5:231.

Kell DB, Swainston N, Pir P, and Oliver SG. 2015. Membrane transporter engineering in industrial biotechnology and whole-cell biocatalysis. Trends Biotechnol 33:237-246.

Kleinstiver BP, Prew MS, Tsai SQ, Topkar VV, Nguyen NT, Zheng Z, Gonzales APW, Li Z, Peterson RT, Yeh JR, Aryee MJ, and Joung JK. 2015. Engineered CRISPR-Cas9 nucleases with altered PAM specificities. Nature 523:481-485.

Knight CG, Platt M, Rowe W, Wedge DC, Khan F, Day P, McShea A, Knowles J, and Kell DB. 2009. Arraybased evolution of DNA aptamers allows modelling of an explicit sequence-fitness landscape. Nucleic Acids Res 37:e6.

Krogsgaard-Larsen P, Liljefors T, and Madsen U. 1996. A textbook of drug design and development, 2nd Ed. New York: Harwod Academic Publishers.

Landowski CP, Anderle P, Sun D, Sadee W, and Amidon GL. 2004. Transporter and ion channel gene expression after Caco-2 cell differentiation using 2 different microarray technologies. Aaps $J$ 6:e21.

Lanthaler K, Bilsland E, Dobson P, Moss HJ, Pir P, Kell DB, and Oliver SG. 2011. Genome-wide assessment of the carriers involved in the cellular uptake of drugs: a model system in yeast. BMC Biol 9:70.

Law V, Knox C, Djoumbou Y, Jewison T, Guo AC, Liu Y, Maciejewski A, Arndt D, Wilson M, Neveu V, Tang A, Gabriel G, Ly C, Adamjee S, Dame ZT, Han B, Zhou Y, and Wishart DS. 2014. DrugBank 4.0: shedding new light on drug metabolism. Nucleic Acids Res 42:D1091-1097.

Li X, Gianoulis TA, Yip KY, Gerstein M, and Snyder M. 2010. Extensive in vivo metabolite-protein interactions revealed by large-scale systematic analyses. Cell 143:639-650. 
Lin X, Skolnik S, Chen X, and Wang J. 2011. Attenuation of intestinal absorption by major efflux transporters: quantitative tools and strategies using a Caco-2 model. Drug Metab Dispos 39:265274.

Maeder ML, Linder SJ, Cascio VM, Fu Y, Ho QH, and Joung JK. 2013. CRISPR RNA-guided activation of endogenous human genes. Nat Methods 10:977-979.

Maldonado AG, Doucet JP, Petitjean M, and Fan BT. 2006. Molecular similarity and diversity in chemoinformatics: from theory to applications. Mol Divers 10:39-79.

Marino AM, Yarde M, Patel H, Chong S, and Balimane PV. 2005. Validation of the 96 well Caco-2 cell culture model for high throughput permeability assessment of discovery compounds. Int $J$ Pharm 297:235-241.

Matsson P, Fenu LA, Lundquist P, Wisńiewski JR, Kansy M, and Artursson P. 2015a. Quantifying the impact of transporters on cellular drug permeability. Trends Pharmacol Sci 36:255-262.

Matsson P, Fenu LA, Lundquist P, Wisńiewski JR, Kansy M, and Artursson P. 2015b. Supplementary Information: addendum to 'Quantifying the impact of transporters on cellular drug permeability'. Trends Pharmacol Sci 36:in press.

Mazanetz MP, Marmon RJ, Reisser CBT, and Morao I. 2012. Drug discovery applications for KNIME: an open source data mining platform. Curr Top Med Chem 12:1965-1979.

Mendes P, Oliver SG, and Kell DB. 2015. Fitting transporter activities to cellular drug concentrations and fluxes: why the bumblebee can fly. Trends Pharmacol Sci:in press.

Mestres J, and Gregori-Puigjané E. 2009. Conciliating binding efficiency and polypharmacology. Trends Pharmacol Sci 30:470-474.

Ming X, Ju W, Wu H, Tidwell RR, Hall JE, and Thakker DR. 2009. Transport of dicationic drugs pentamidine and furamidine by human organic cation transporters. Drug Metab Dispos 37:424430.

Nigam SK. 2015. What do drug transporters really do? Nat Rev Drug Discov 14:29-44.

Niphakis MJ, Lum KM, Cognetta AB, Correia BE, Ichu TA, Olucha J, Brown SJ, Kundu S, Piscitelli F, Rosen H, and Cravatt BF. 2015. A Global Map of Lipid-Binding Proteins and Their Ligandability in Cells. Cell 161:1668-1680.

O'Hagan S, and Kell DB. 2015a. Software review: The KNIME workflow environment and its applications in Genetic Programming and machine learning. Genetic Progr Evol Mach 16:387-339.

O'Hagan S, and Kell DB. 2015b. Understanding the foundations of the structural similarities between marketed drugs and endogenous human metabolites. Front Pharmacol 6:105.

O'Hagan S, Swainston N, Handl J, and Kell DB. 2015. A 'rule of $0.5^{\prime}$ for the metabolite-likeness of approved pharmaceutical drugs. Metabolomics 11:323-339.

Peng Y, Yadava P, Heikkinen AT, Parrott N, and Railkar A. 2014. Applications of a 7-day Caco-2 cell model in drug discovery and development. Eur J Pharm Sci 56:120-130.

Press B. 2011. Optimization of the Caco-2 permeability assay to screen drug compounds for intestinal absorption and efflux. Methods Mol Biol 763:139-154.

Pshezhetsky AV, Fedjaev M, Ashmarina L, Mazur A, Budman L, Sinnett D, Labuda D, Beaulieu JF, Menard D, Nifant'ev I, and Levy E. 2007. Subcellular proteomics of cell differentiation: quantitative analysis of the plasma membrane proteome of Caco-2 cells. Proteomics 7:2201-2215.

Riniker S, and Landrum GA. 2013. Open-source platform to benchmark fingerprints for ligand-based virtual screening. $J$ Cheminform 5:26.

Rubas W, Cromwell ME, Shahrokh Z, Villagran J, Nguyen TN, Wellton M, Nguyen TH, and Mrsny RJ. 1996. Flux measurements across Caco-2 monolayers may predict transport in human large intestinal tissue. J Pharm Sci 85:165-169.

Sahoo S, Aurich MK, Jonsson JJ, and Thiele I. 2014. Membrane transporters in a human genome-scale metabolic knowledgebase and their implications for disease. Frontiers in physiology 5:91. 
Sarmento B, Andrade F, da Silva SB, Rodrigues F, das Neves J, and Ferreira D. 2012. Cell-based in vitro models for predicting drug permeability. Expert Opin Drug Metab Toxicol 8:607-621.

Saubern S, Guha R, and Baell JB. 2011. KNIME Workflow to Assess PAINS Filters in SMARTS Format. Comparison of RDKit and Indigo Cheminformatics Libraries. Mol Inform 30:847-850.

Skolnik S, Lin X, Wang J, Chen XH, He T, and Zhang B. 2010. Towards prediction of in vivo intestinal absorption using a 96-well Caco-2 assay. J Pharm Sci 99:3246-3265.

Sugiyama Y, and Steffansen B. 2013. Transporters in Drug Development: Discovery, Optimization, Clinical Study and Regulation. New York: AAPS/Springer.

Sun D, Lennernäs H, Welage LS, Barnett JL, Landowski CP, Foster D, Fleisher D, Lee KD, and Amidon GL. 2002. Comparison of human duodenum and Caco-2 gene expression profiles for 12,000 gene sequences tags and correlation with permeability of 26 drugs. Pharm Res 19:1400-1416.

Sun H, Chow EC, Liu S, Du Y, and Pang KS. 2008. The Caco-2 cell monolayer: usefulness and limitations. Expert Opin Drug Metab Toxicol 4:395-411.

Swainston N, Mendes P, and Kell DB. 2013. An analysis of a 'community-driven' reconstruction of the human metabolic network. Metabolomics 9:757-764.

Thiele I, Swainston N, Fleming RMT, Hoppe A, Sahoo S, Aurich MK, Haraldsdottír H, Mo ML, Rolfsson O, Stobbe MD, Thorleifsson SG, Agren R, Bölling C, Bordel S, Chavali AK, Dobson P, Dunn WB, Endler L, Goryanin I, Hala D, Hucka M, Hull D, Jameson D, Jamshidi N, Jones J, Jonsson JJ, Juty N, Keating S, Nookaew I, Le Novère N, Malys N, Mazein A, Papin JA, Patel Y, Price ND, Selkov Sr. E, Sigurdsson MI, Simeonidis E, Sonnenschein N, Smallbone K, Sorokin A, Beek HV, Weichart D, Nielsen JB, Westerhoff HV, Kell DB, Mendes P, and Palsson B $\varnothing$. 2013. A community-driven global reconstruction of human metabolism. Nat Biotechnol 31:419-425.

Uchida M, Fukazawa T, Yamazaki Y, Hashimoto H, and Miyamoto Y. 2009. A modified fast (4 day) 96-well plate Caco-2 permeability assay. J Pharmacol Toxicol Methods 59:39-43.

Usansky HH, and Sinko PJ. 2005. Estimating human drug oral absorption kinetics from Caco-2 permeability using an absorption-disposition model: model development and evaluation and derivation of analytical solutions for $\mathrm{k}_{\mathrm{a}}$ and $\mathrm{F}_{\mathrm{a}}$. J Pharmacol Exp Ther 314:391-399.

van Breemen RB, and Li Y. 2005. Caco-2 cell permeability assays to measure drug absorption. Expert Opin Drug Metab Toxicol 1:175-185.

van De Waterbeemd H, and Testa B. 2009. Drug Bioavailability: Estimation of Solubility, Permeability, Absorption and Bioavailability. Weinheim: Wiley.

Volpe DA. 2011. Drug-permeability and transporter assays in Caco-2 and MDCK cell lines. Future Med Chem 3:2063-2077.

Wang T, Wei JJ, Sabatini DM, and Lander ES. 2014. Genetic screens in human cells using the CRISPR-Cas9 system. Science 343:80-84.

Wang Y, Cao J, Wang X, and Zeng S. 2010. Stereoselective transport and uptake of propranolol across human intestinal Caco-2 cell monolayers. Chirality 22:361-368.

Winter GE, Radic B, Mayor-Ruiz C, Blomen VA, Trefzer C, Kandasamy RK, Huber KVM, Gridling M, Chen D, Klampfl T, Kralovics R, Kubicek S, Fernandez-Capetillo O, Brummelkamp TR, and Superti-Furga G. 2014. The solute carrier SLC35F2 enables YM155-mediated DNA damage toxicity. Nat Chem Biol 10:768-773.

You G, and Morris ME. 2014. Drug Transporters: Molecular Characterization and Role in Drug Disposition. In: Wang B, editor. 2nd ed. New York: Wiley.

Zhou Y, Zhu S, Cai C, Yuan P, Li C, Huang Y, and Wei W. 2014. High-throughput screening of a CRISPR/Cas9 library for functional genomics in human cells. Nature 509:487-491. 


\section{1}

A compilation of 15 review articles on Caco-2 permeability measurements.

A. Full dataset, including outliers. B. Reduced dataset after removal of the data from ( Avdeef et al. 2005 ) . C. Cumulative plot and smoothed histogram of the Caco-2 permeabilities in the reduced dataset. In Figure $1 \mathrm{C}$ data for identical drugs were averaged. Data were extracted from the following papers. 1 ( Bergström et al. 2003 ) ; 2 ( Hou et al. 2004 ) ; 3 ( Corti et al. 2006 ) ; 4 ( Balimane et al. 2006 ) ; 5 ( Gozalbes et al. 2011 ) ; 6 ( Peng et al. 2014 ) ; 7 ( Press 2011 ) ; 8 ( Usansky \& Sinko 2005 ) ; 9 ( Marino et al. 2005 ) ; 10 ( Avdeef et al. 2005 ) ; 11 ( Hayeshi et al. 2008 ) ; 12 (Wang et al. 2010 ) ; 13 ( Uchida et al. 2009 ) ; 14 ( Skolnik et al. 2010 ) ; 15 ( Lin et al. 2011 ) 
A

\section{Initial full dataset}

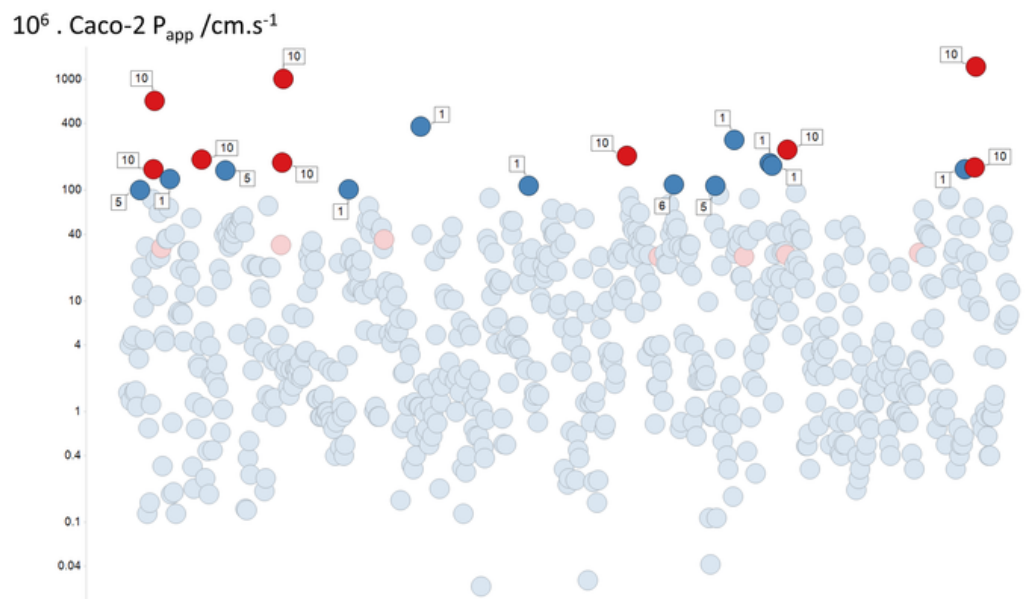

Various marketed drugs

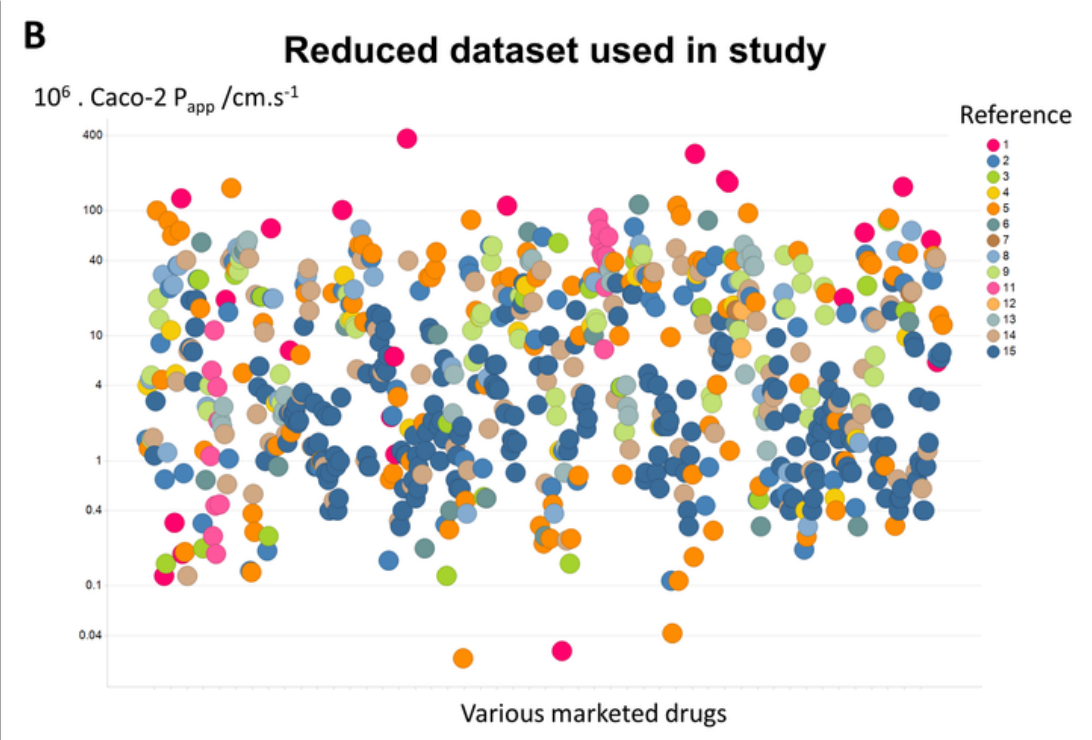

C

Cumulative $P_{\text {app }}$ values for 187 marketed drugs
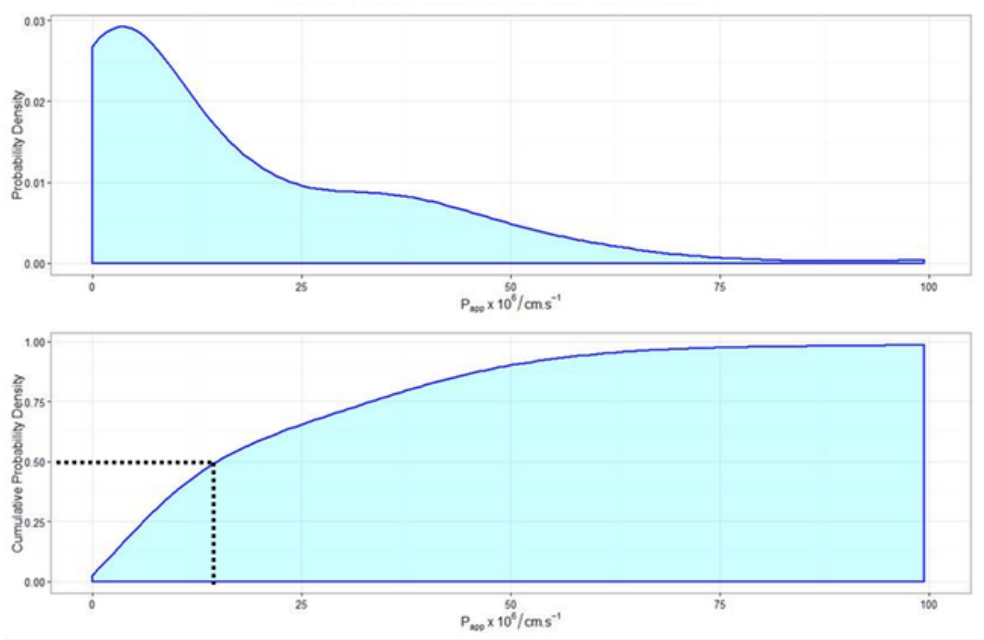

PeerJ reviewing PDF | (2015:07:6022:2:0:REVIEW 16 Oct 2015) $10^{6} \cdot \mathrm{P}_{\text {app }} / \mathrm{cm} \cdot \mathrm{s}^{-1}$ 
2

Relative lack of effect of efflux inhibitors on Caco-2 permeabilities of marketed drugs.

Data are taken from ( Lin et al. 2011 ) and shown as paired values.

\section{Effects of efflux inhibitors on Caco-2 permeability}

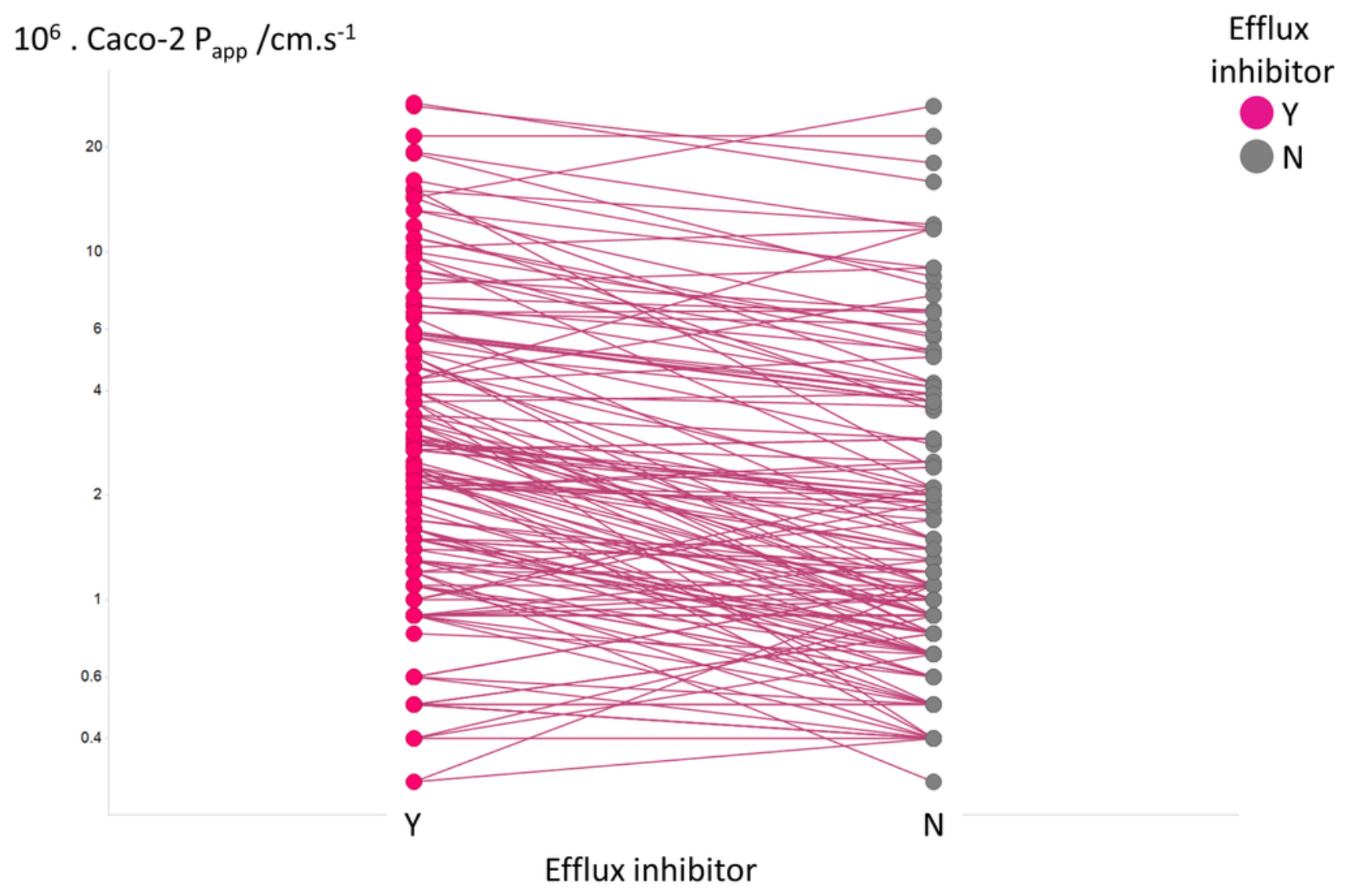


3

Lack of relationship between Caco-2 cells and simple biophysical parameters.

A. Caco-2 permeability as a function of MW. B. Caco-2 permeability as a function of SlogP. C. Caco-2 permeability as a function of Total Polar Surface Area. D. Lack of relationship between Total Polar Surface Area and S log P. 5 
A

Lack of relationship between Caco-2 permeability and MW $10^{6}$. Caco- $2 \mathrm{P}_{\text {app }} / \mathrm{cm}^{-1}$

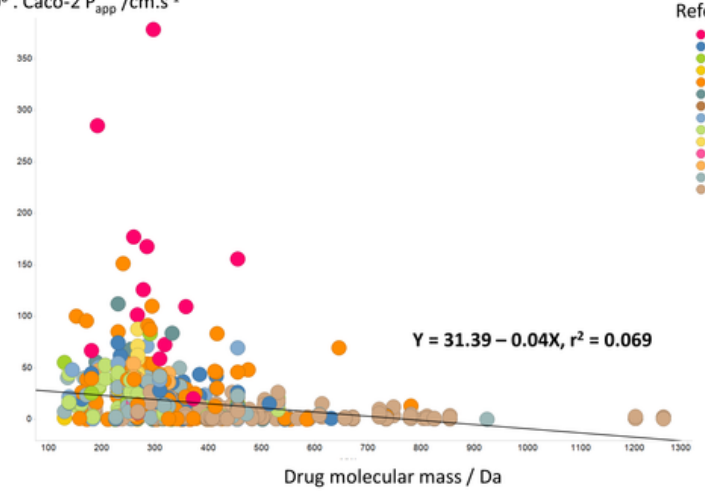

B

Lack of relationship between Caco-2 permeability and SlogP

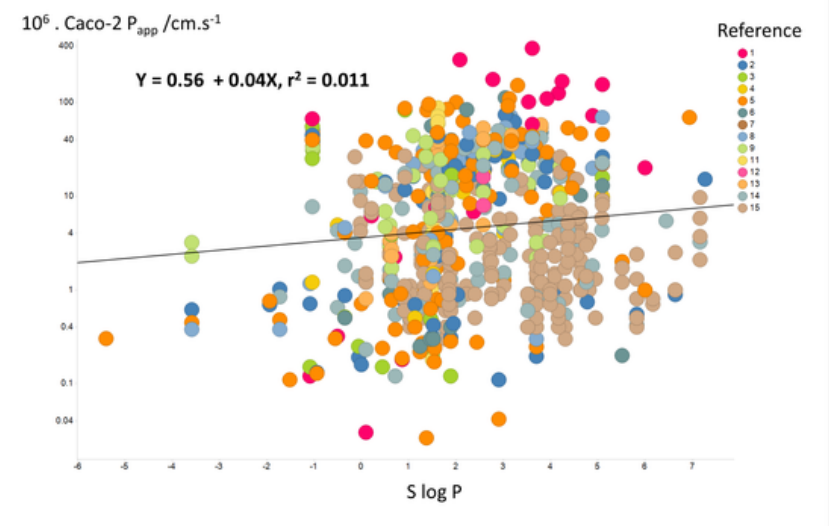

C

Lack of relationship between Caco-2 permeability and TPSA

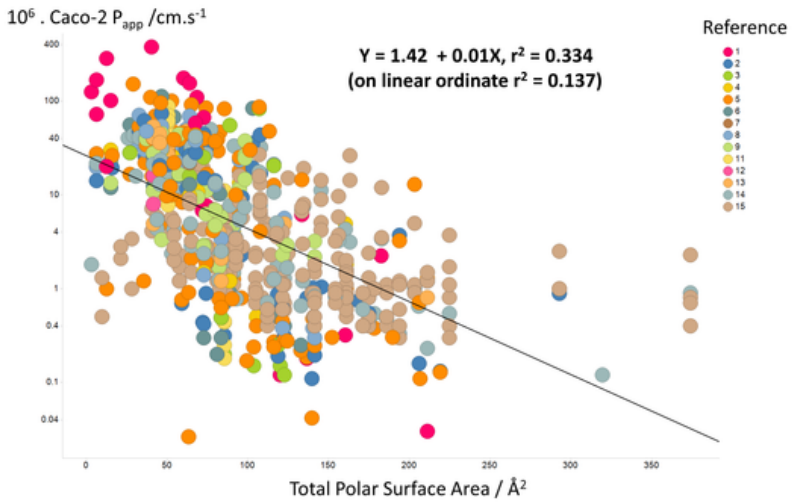

D

Lack of relationship between Caco-2 TPSA and SlogP

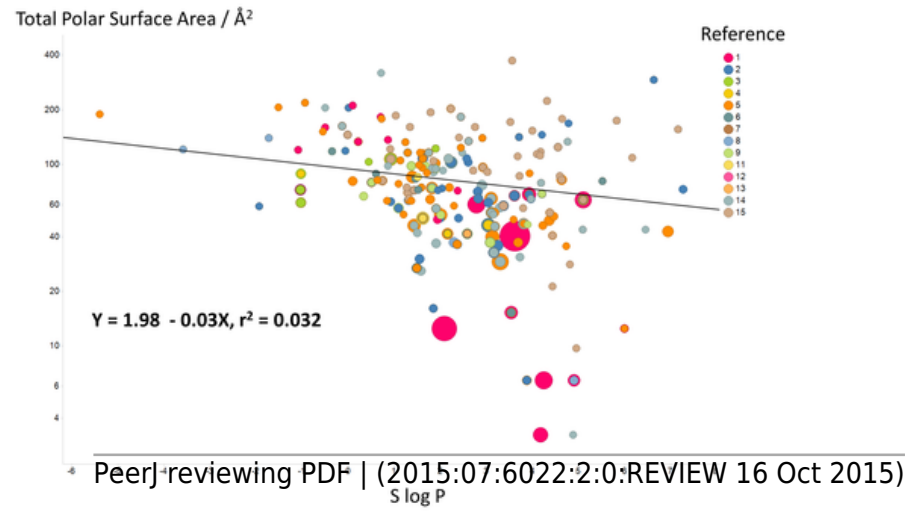




\section{4}

Lack of relationship between Caco-2 cell permeability and measures of endogenitelikeness.

A. Lack of relationship between the $\mathrm{P}_{\mathrm{app}}$ of a drug in Caco-2 cells and its greatest Tanimoto similarity to any endogenite molecule in Recon2. B. Lack of relationship between the $P_{\text {app }}$ of a drug and the number of endogenous metabolites (endogenites) in Recon2 possessing a Tanimoto similarity greater than 0.65 .187 different drugs were assessed in each case. 
A

Lack of relationship between $\mathrm{P}_{\mathrm{app}}$ and Max TS

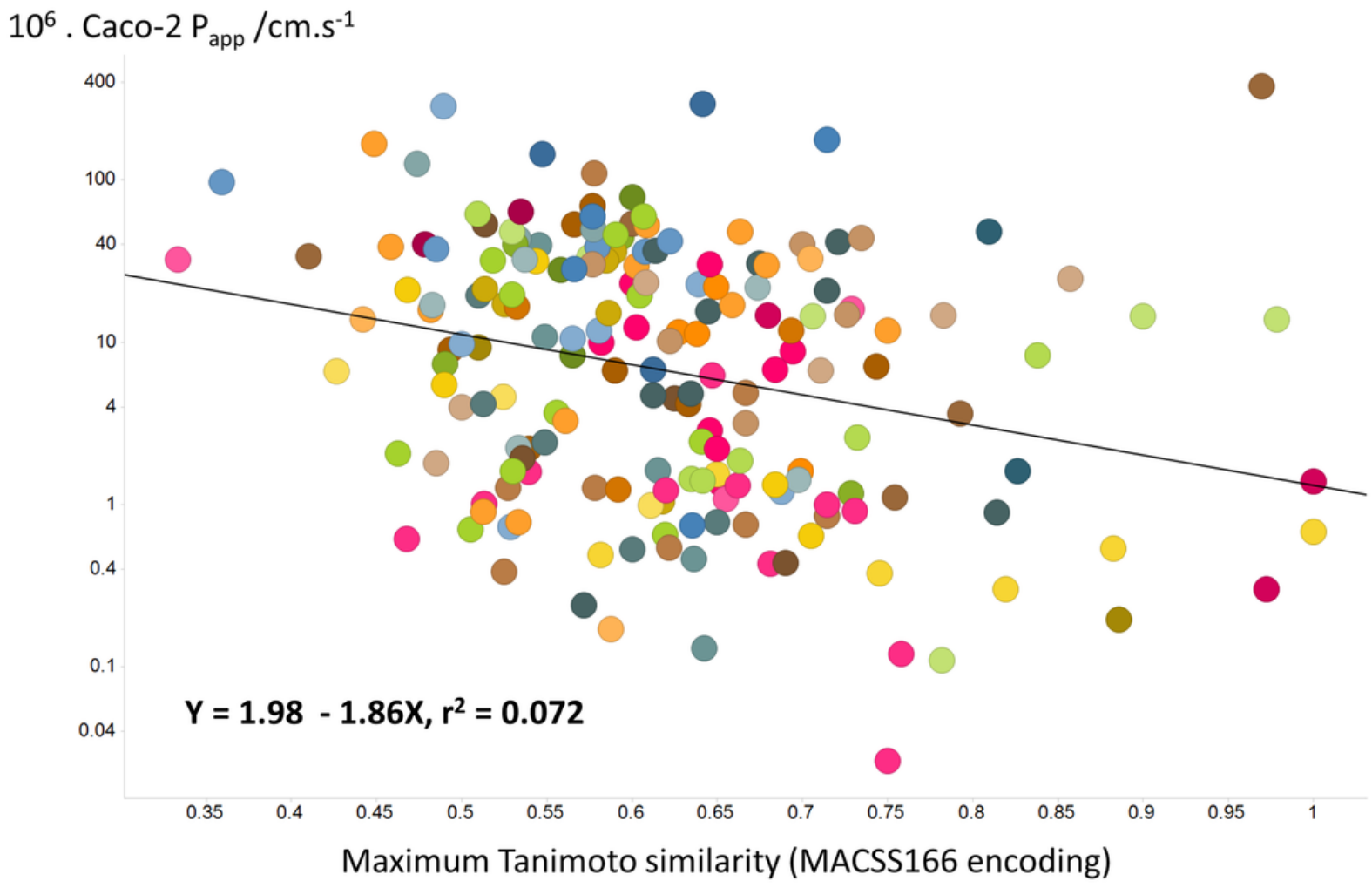

\section{B Lack of relationship between $P_{\text {app }}$ and number of endogenites with a TS > 0.65}

$10^{6}$. Caco-2 $\mathrm{P}_{\mathrm{app}} / \mathrm{cm} \cdot \mathrm{s}^{-1}$

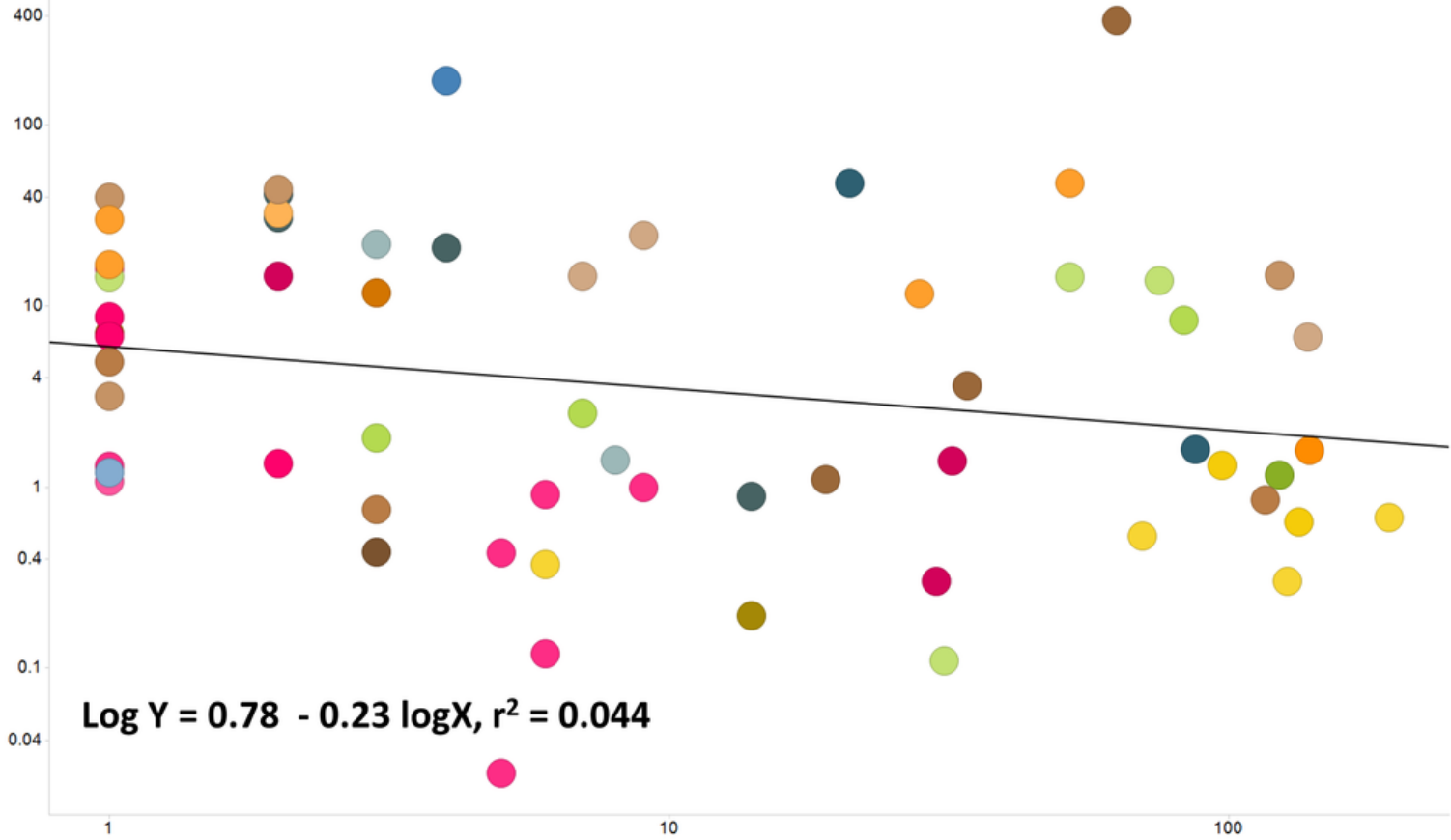

Number of endogenites with Tanimoto similarity $>0.65$ (DESencoding) 


\section{5}

Lack of relationship between experimental Caco-2 permeabilities and those predicted (via out-of-bag estimation) from a random forest learner.

Drug properties were encoded using either the MACCS166 encoding ( O'Hagan et al. 2015 ) or the full DES encoding ( O'Hagan \& Kell 2015b ), each together with the molecular properties encoded in the CDK KNIME node ( Beisken et al. 2013 ) .

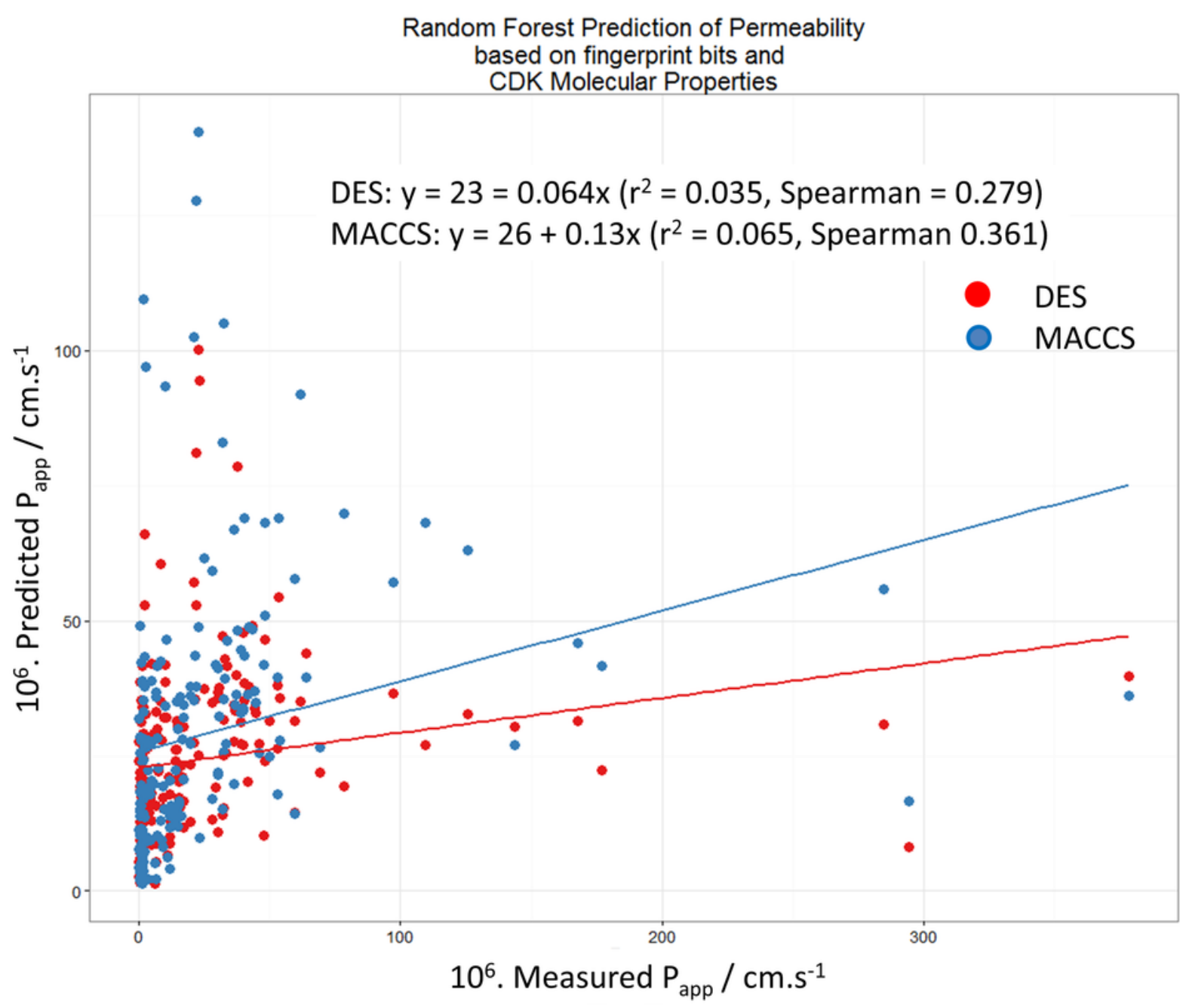




\section{Table $\mathbf{1}$ (on next page)}

Table 1 
1 Table 1. Further details of the 15 transporter studies reviewed.

\begin{tabular}{|c|c|c|c|}
\hline Drug concentration(s) & Insert type & $\begin{array}{l}\text { Shaking or stirring } \\
\text { speeds given }\end{array}$ & Reference \\
\hline $0.02-6 \mathrm{mM}$ & $\begin{array}{l}\text { Polycarbonate filter } \\
\text { inserts, } 12 \mathrm{~mm} \\
\text { diameter; pore size } 0.4 \\
\mu \mathrm{m} \text {; Costar }\end{array}$ & Mainly 500 rpm & Bergström et al. 2003 \\
\hline 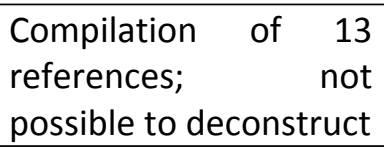 & & & Hou et al. 2004 \\
\hline Not actually stated & $\begin{array}{l}\text { Polycarbonate filters } \\
\left(\text { area } 1.13 \mathrm{~cm}^{2}\right) \text { in } \\
\text { Costar Snapwell six- } \\
\text { well plates }\end{array}$ & Not stated & Corti et al. 2006 \\
\hline $100-200 \mu \mathrm{M}$ & $\begin{array}{lr}\begin{array}{l}\text { Corning } \\
\text { polycarbonate }\end{array} & \text { 24-well } \\
\text { membrane } & \text { filter } \\
\text { Transwell inserts, } \\
\text { surface area: } 0.33 \mathrm{~cm}^{2}\end{array}$ & Not stated & Balimane et al. 2006 \\
\hline $10 \mu \mathrm{M}$ & $\begin{array}{l}\text { Fibrillar collagen } \\
\text { coated PET membrane } \\
\text { inserts in 24-well } \\
\text { plates (BD Biosciences) }\end{array}$ & Not stated & Gozalbes et al. 2011 \\
\hline $10 \mu \mathrm{M}$ & $\begin{array}{l}\text { Collagen-coated } \\
\text { transwell plates }\end{array}$ & $100 \mathrm{rpm}$ & Peng et al. 2014 \\
\hline $1-10 \mu \mathrm{M}$ & $\begin{array}{l}\text { (24-well systems from } \\
\text { BD BioSciences (PET } \\
\text { membrane, } 1.0 \mathrm{~mm} \text {, } \\
\text { cat. \#351181) or } \\
\text { Costar (polycarbonate } \\
\text { membrane, } 0.4 \mathrm{~mm} \text {, } \\
\text { cat. \#3396). }\end{array}$ & 30 rpm & Press 2011 \\
\hline $\begin{array}{l}\text { Compilation; not } \\
\text { possible to deconstruct }\end{array}$ & & & Usansky \& Sinko 2005 \\
\hline $5 \mu \mathrm{M}$ & 'filter membranes' & Not stated & Marino et al. 2005 \\
\hline $50 \mathrm{nM}-100 \mu \mathrm{M}$ & $\begin{array}{l}\text { Polycarbonate filter } \\
\text { inserts } \quad \text { (Transwell }^{\circledR} \\
\text { Costar; mean pore size } \\
0.45 \mu \mathrm{m} \text {; diameters } 12 \\
\mathrm{~mm} \text { ) }\end{array}$ & $25-7000 \mathrm{rpm}$ & Avdeef et al. 2005 \\
\hline $\begin{array}{l}\text { Mostly } 30 \mu \mathrm{M}, \\
\text { occasionally } 100 \mu \mathrm{M}\end{array}$ & $\begin{array}{l}\text { Polycarbonate, } 0.4-3 \\
\mu \mathrm{m}, 6 \mathrm{~mm} \text { or } 12 \mathrm{~mm}\end{array}$ & Not stated & Hayeshi et al. 2008 \\
\hline $10-500 \mu \mathrm{M}$ & $\begin{array}{l}\text { 12-well Transwell } \\
\text { plate with clear } \\
\text { polyester membrane } \\
\text { insert }(0.4 \mu \mathrm{m} \text { pore }\end{array}$ & $50 \mathrm{rpm}$ & Wang et al. 2010 \\
\hline
\end{tabular}




\begin{tabular}{|l|l|l|l|}
\hline $20 \mu \mathrm{M}$ & $\begin{array}{l}\text { diameter, 12 mm } \\
\text { diameter), Corning } \\
\text { Costar }\end{array}$ & & \\
\hline 'Collagen-coated & Not stated & Uchida et al. 2009 \\
inserts' & "96-Multiwell Insert \\
System from BD but rate not & Skolnik et al. 2010 \\
Biosciences" & stated & Lin et al. 2011 \\
\hline $10 \mu \mathrm{M}$ & $\begin{array}{l}\text { Six-well Transwell } \\
\text { polycarbonate Not stated } \\
\text { membrane inserts, } \\
\text { Corning Life Science }\end{array}$ & & \\
\hline
\end{tabular}

2 